[The Editors of the Journal of General Microbiology accept no responsibility for the Reports of the Proceedings of the Society. Abstracts of papers are published as received from authors.]

\title{
THE SOCIETY FOR GENERAL MICROBIOLOGY
}

The Society for General Microbiology held its thirty-sixth General Meeting in the University of Sheffield, on Monday and Tuesday, 7 and 8 January 1963. The following communications were made:

\section{SYMPOSIUM: SOME GOMPARATIVE ASPECTS OF INTERMEDIARY METABOLISM IN MICRO-ORGANISMS}

\author{
MoNDAY, 7 January
}

Comparative Aspects of Alcohol Formation. By E. A. DAwes (Department of Biochemistry, University of Glasgow)

The Microbiological Degradation of Aromatic Compounds. By W. C. Evans (Department of Biochemistry and Soil Science, University College of North Wales, Bangor)

The Breakdown and Biosynthesis of Glutamic Acid. By D. S. HoARe (Department of Microbiology, University of Sheffield)

The Assimilation of 1-G Gompounds. By J. R. Quayle (Department of Biochemistry, University of Oxford)

The Assimilation of 2-C Compounds Excluding Acetate. By J. G. Morris (Department of Biochemistry, University of Leicester)

Storage Products. By J. F. WiLkinson (Department of Bacteriology, University of Edinburgh)

Abbreviated versions of these contributions will shortly be published in the Journal of General Microbiology.

\section{ORIGINAL PAPERS}

Tuesday, 8 January

Methanol Oxidation in Pseudomonas sp. M27. By C. Anthony and L. J. Zatman (Department of Microbiology, University of Reading)

Pseudomonas sp. M27, isolated from soil, grows aerobically on methanol as sole source of carbon and energy; it is very similar to Pseudomonas sp. AM1 of Peel \& Quayle ((1961), Biochem. J. 81, 465). Oxygen uptake in the presence of methanol by washed suspensions of methanol-grown $\mathrm{M} 27$ is completely inhibited by $10^{-5} \mathrm{M}-p$-nitrophenylhydrazine, $10^{-4} \mathrm{M}$ phenylhydrazine and $5 \times 10^{-3} \mathrm{M}$-EDTA, without affecting the catalase activity (oxygen production from $\mathrm{H}_{2} \mathrm{O}_{2}$ ). Conversely, methanol oxidation is inhibited only $50 \%$ by azide or hydroxylamine $\left(4 \times 10^{-3} \mathrm{M}\right)$, whilst catalase activity is completely inhibited. These results appear to preclude the catalatic mechanism of methanol oxidation proposed by Harrington \& Kallio ((1960), Canad. J. Microbiol. 6, 1). With methanol as substrate, cellfree sonicates catalyse reduction of phenazine methosulphate (PMS) anaerobically in Thunberg tubes. In the presence of PMS the reaction can be followed either manometrically with oxygen as final acceptor or spectrophotometrically with 2,6-dichlorophenolindophenol (PIP) or cytochrome $c$ as the final acceptor. Partially purified enzyme preparations lose some activity on dilution and all activity is lost on dialysis against $0.05 \mathrm{M}$-phosphate buffer 
$\left(\mathrm{pH} \mathrm{7 \cdot 0)}\right.$. Activity of dialysed preparations is restored completely by $5 \times 10^{-3} \mathrm{M}$-ammonium salts and partially by methylamine hydrochloride; salts of $\mathrm{Li}, \mathrm{Na}, \mathrm{K}, \mathrm{Rb}, \mathrm{Mg}$ or $\mathrm{Ca}$, and of dimethylamine, triethylamine, tetramethylamine, aniline or choline have no effect. The reaction rate in the PMS/PIP system is directly proportional to enzyme and PIP concentrations and is maximal at $\mathrm{pH} \mathrm{9.0.} \mathrm{There} \mathrm{is} \mathrm{no} \mathrm{inhibition} \mathrm{by} \mathrm{cyanide,} \mathrm{EDTA} \mathrm{or} \mathrm{phenyl-}$ hydrazine, all at $10^{-3} \mathrm{M}$. Contrary to the findings of Kaneda \& Roxburgh ((1959), Canad.J. Microbiol. 5, 187) no reduction of NAD or NADP in the presence of methanol has been observed. Our present data thus suggest that the oxidation of methanol in Pseudomonas sp. M27 involves a new alcohol dehydrogenase which does not require a nicotinamide nucleotide coenzyme.

The Relation between Growth and Oxygen Consumption in Micro-organisms. By A. M. Whitaker and S. R. Elsden (A.R.C. Unit for Microbiology, Department of Microbiology, University of Sheffield)

We have measured the dry weight of cells produced and the amount of oxygen consumed by cultures of micro-organisms growing in media in which the energy source is the factor limiting growth. Sterile Warburg flasks containing sterile medium and $0.2 \mathrm{ml} .10 \%(\mathrm{w} / \mathrm{v})$ $\mathrm{NaOH}$ in the centre well were inoculated and the oxygen uptake during growth measured. The end of growth was indicated by a fall in the rate of oxygen consumption to a 'resting' level. At this point the cell density was estimated either turbidimetrically or by determining the total perchloric acid-precipitable organic matter by the method of Johnson ((1949), J.biol.Chem.181,707). Growth was proportional to the amount of oxygen consumed and the coefficient: $g$. dry wt./mole $\mathrm{O}_{2}\left(\mathrm{Y}_{\mathrm{O}_{2}}\right)$ was constant. In general the value for $\mathrm{Y}_{\mathrm{O}_{2}}$ increased with the complexity of the energy source. Thus for Pseudomonas fluorescens $\mathrm{KB}_{1}$, growing upon acetate, succinate and citrate, the mean values for $\mathrm{Y}_{\mathrm{O}_{2}}$ were 14.9, 20.7 and 26.4, respectively. When this organism was grown on benzoate or nicotinate, the values for $\mathrm{Y}_{\mathrm{O}_{2}}$ were less than those obtained when the organism was grown on equimolecular mixtures of the products of ring fission. The values for benzoate and for succinate + acetate were 17 and $21 \cdot 9$, respectively; for nicotinate and fumarate + formate 11 and $17 \cdot 6$, respectively. These results are in keeping with the view that the oxygen used for ring fission does not participate in oxidative phosphorylation.

Escherichia coli, Torula utilis and Acetobacter suboxydans 621 growing on glucose gave values for $\mathrm{Y}_{\mathrm{O}_{2}}$ of $40 \cdot 4,42 \cdot 3$ and $9 \cdot 8$, respectively. These results suggest that $A$. suboxydans uses oxygen less efficiently than either $E$. coli or $T$. utilis.

Photoassimilation of Acetate by the Green Sulphur Bacterium Chlorobium thiosulphatophilum. By J. GrBson and D. S. HoAre (Agricultural Research Council Unit for Microbiology, University of Sheffield)

Growing cultures of Chlorobium limicola assimilate acetate into cell material provided sulphide, as a source of reducing power, and bicarbonate are present (Sadler \& Stanier (1960), Proc. Nat. Acad. Sci., Wash. 46, 1329). The effect of acetate on cell yield has been investigated with the closely related bacterium Chlorobium thiosulphatophilum. Low concentrations of acetate increase the rate of growth and final cell yield with maximum effects at $0.005 \mathrm{M}$ acetate. With resting cell suspensions, the presence of acetate decreased the rate at which radioactive carbon dioxide was assimilated during photosynthesis in $95 \%$ $\mathrm{H}_{2}+5 \% \mathrm{CO}_{2}$. Resting cell suspensions assimilate [1-] and [2-14 $\left.\mathrm{C}\right]$ acetate provided the system is illuminated, a source of reducing power, such as hydrogen, is available, and carbon dioxide is present. The finding that bicarbonate is essential for the assimilation of acetate by resting cell suspensions of $C$. thiosulphatophilum contrasts with similar experiments with Rhodospirillum rubrum (Stanier, R. Y. et al. (1959), Proc. Nat. Acad. Sci., Wash. 45,1246 ) where it was found that acetate is photoassimilated in the absence of bicarbonate to poly- $\beta$-hydroxybutyrate. Poly- $\beta$-hydroxybutyrate has not been found either in cultures grown in the presence of acetate or in resting cell suspensions exposed to acetate in the 
light. Carbon dioxide present during the photo-assimilation of $[1-]$ and $\left[2-{ }^{14} \mathrm{C}\right]$ acetate by resting cell suspensions did not contain radioactivity after $2 \mathrm{hr}$. exposure in the light, suggesting that acetate is not oxidized under these conditions. The crude protein fraction obtained by the procedure of Roberts et al. ((1955), Studies of Biosynthesis in Escherichia coli. Carnegie Instn. of Washington Publication 607, Washington D.C.), has been hydrolysed and amino acids have been separated and identified by paper electrophoresis and paper chromatography coupled with radioautography. Both [1-] and $\left[2{ }^{14} \mathrm{C}\right]$ acetate appear to be incorporated into all the common amino acids. The distribution of radioactivity in the amino acids is being investigated by unequivocal degradation procedures.

The Metabolism of Erythritol by a Virulent Strain of Brucella abortus. By J. D. Anderson and H. Smith (Microbiological Research Establishment, Porton, Wiltshire)

Foetal erythritol appears to explain the preferential growth of Brucella abortus in foetal tissue during bovine brucellosis. The polyol $(0.001 \mu \mathrm{mole} / \mathrm{ml}$.) stimulated the growth of $B r$. abortus in bovine phagocytes and laboratory media and enhanced an infection in vivo (Smith, H. et al. (1962), Nature, Lond. 193, 47). Erythritol was known to be the best of nine carbohydrates when used as sole carbon source for $B r$. abortus in a simple medium (McCullough, N. B. \& Beal, G. A. (1951), J. Infect. Dis. 89, 266). However, our interest in the function of erythritol in vivo prompted an investigation into its metabolism by $B r$. abortus (strain 544) growing $\left(37^{\circ}\right.$, shake flasks, $5 \% \mathrm{CO}_{2} /$ air) in a complex defined medium (based on that of Rode, L. J., Oglesby, G. \& Schuhardt, V. T. (1950), J. Bacteriol. $60,661)$ and in the presence of adequate carbohydrate $(38 \mu \mathrm{mole} / \mathrm{ml}$. D-glucose). Kinetic studies and erythritol determinations during growth in the latter medium showed that erythritol $(0.005-1.0 \mu \mathrm{mole} / \mathrm{ml}$.) stimulated growth of the organism approximately twofold and that low concentrations of erythritol were only effective for small populations. Despite the high D-glucose concentration in these experiments, $B r$. abortus used more than its own weight of the polyol during growth. Radiotracer investigations confirmed these conclusions and showed that as soon as $0.5 \mu \mathrm{mole} / \mathrm{ml}$. of $\mathrm{U}-\left[{ }^{14} \mathrm{C}\right]$ erythritol had disappeared from the medium after growth of $\mathrm{Br}$. abortus from about $2 \times 10^{7}$ to about $1 \times 10^{9}$ cells $/ \mathrm{ml}$., the distribution of $\left[{ }^{14} \mathrm{C}\right]$ was approximately: carbon dioxide $45 \%$, bacteria $25 \%$ and medium $30 \%$. The nature of material remaining in the medium is under investigation.

Erythritol, its Effect on the Growth of Various Strains of Brucella abortus and its Possible Significance in Infections with Brucella melitensis and Brucella suis. By A. E. Williams, J. Keppie and H. Smitir (Microbiological Research Establishment, Porton, Wiltshire)

The predilection of Brucella abortus for bovine foetal fluids and placenta is probably due to the presence in these tissues of erythritol-a growth stimulant for this organism (Smith, H. et al. (1962), Nature, Lond. 193, 47). This work in the bovine was done with a single virulent strain of $B r$. abortus. It remained to be seen whether different strains of $B r$. abortus would be similarly stimulated by erythritol and whether the presence of erythritol could explain the localization of $\mathrm{Br}$. melitensis in goats and sheep and $\mathrm{Br}$. suis in pigs. When a number of strains of $B r$. abortus were examined for the effect of erythritol on their growth, not only were other virulent strains stimulated but there was a good correlation between degree of virulence (for guinea-pigs) and the extent of growth-stimulation by erythritol. Thus, in a mixture of tryptic meat broth (1 part) and Locke solution (1 part), erythritol stimulated the growth of seven virulent smooth strains to a greater extent than it did four attenuated smooth strains and one avirulent smooth strain. The relevance of these findings to the pathogenesis of bovine brucellosis is being studied. With regard to brucellosis in other hosts, significant amounts of erythritol were found in the placenta of animals, such as goats, sheep and pigs, that in brucellosis suffer a heavy infection of the placenta, but not in human placenta or in that of the rat, rabbit or guinea-pig which do not show the characteristic placentitis. Furthermore, the growth of virulent strains of Br. melitensis and 
$B r$. suis was significantly stimulated by adding erythritol to cultures in a serum medium and a tryptic meat broth for Br. melitensis, and a defined medium (McCullough, N. B. \& Dick, L. A. (1943), Proc. Soc. exp. Biol., N.Y. 52, 310) for Br. suis.

The Isolation and Composition of Flagella from Crithidia (Strigomonas) oncopelti. By J. K. Chesters (Sub-Department of Chemical Microbiology, Department of Biochemistry, University of Cambridge)

The trypanosomid flagellate, Crithidia oncopelti, used in this investigation, was a strain of the organism first isolated in bacteria-free culture by Noguchi \& Tilden ((1926), J. exp. Med. 44, 307) and named Herpetomonas oncopelti.

Suspensions of the organism $\left(10^{9}\right.$ cells per ml. $)$ in $0.25 \mathrm{M}$ sucrose solution were homogenized for short periods of time in a loosely fitting Potter homogenizer. In this way flagella were detached from the cells with little cell breakage and then isolated by differential centrifugation through sucrose gradients.

The degree of contamination of preparations of flagella with other cell fragments was assessed by phase contrast and electron microscopy; the possibility of contamination with adsorbed soluble materials, liberated by cell breakage, was investigated using ${ }^{14} \mathrm{C}$-labelled cells.

Analysis showed the general composition of the flagella to be: protein, $72 \%$; lipid, $27 \%$; nucleic acid, $0.5 \%$ and carbohydrate, $0.5 \%$. Thirteen per cent of the lipid was shown to be phospholipid, the sole nitrogenous base being ethanolamine. Gas-liquid chromatography of the fatty acids of the lipid identified four major components: palmitic, 15-methylhexadecanoic, oleic and a highly unsaturated $\mathrm{C}_{18}$ acid. In this respect, the lipid from flagella is very similar to that extracted from intact cells.

The amount of nucleic acid in preparations of flagella varied considerably but never exceeded $1.0 \%$. Experiments with ${ }^{14} \mathrm{C}$-adenine-labelled cells suggest that this nucleic acid may arise from contamination with cytoplasm rather than form an integral part of the flagellum.

The Incorporation of ${ }^{14} \mathrm{C}$ Labelled Methionine into Bacterial Flagellin. By D. Kerridge (Sub-Department of Chemical Microbiology, Department of Biochemistry, University of Cambridge)

Flagella from Salmonella typhimurium have been shown to contain the unusual amino acid $\epsilon \mathrm{N}$-methyl lysine (NML) (Ambler \& Rees (1959), Nature, Lond. 186, 56). In cultures of S. typhimurium this amino acid can be labelled with either ${ }^{14} \mathrm{C}$ lysine or ${ }^{14} \mathrm{C}$ methyl labelled methionine. The incorporation of the labelled methyl group from methionine into NML gives a satisfactory measure of the rate of formation of flagella by cultures of S. typhimurium.

The methionine analogues, D-methionine and DL-methionine sulphoxide have no effect on the growth rate of Salmonella typhimurium in a minimal medium, but competitively inhibit the isotopic labelling of the methyl group of NML. DL-ethionine and DL-methionine sulphone also inhibit the methyl labelling of NML.

Flagellin can be detected serologically in the soluble protein fraction of Salmonella typhimurium (cf. Weinstein, Koffler \& Moskowitz (1960), Bact. Proc. p. 63) but using the methyl labelling of NML as a marker it has not been possible to show intracellular precursors of flagella.

Glycine Metabolism in Relation to the Synthesis of Methionine by Escherichia coli. By F. G. Bull and D. D. Woons (Microbiology Unit, Department of Biochemistry, University of Oxford)

Suspensions of Escherichia coli PA 15 (a serine/glycine auxotroph) convert homocysteine to methionine with serine as source of the methyl group. Organisms grown with glycine formed twice as much methionine as those grown with serine and in addition could use glycine as $\mathrm{C}_{1}$ donor (Gibson, F. \& Woods, D. D. (1960), Biochem. J. 79, 160). Serine-grown 
organisms produced equimolar quantities of glycine and methionine; glycine-grown organisms, however, formed only about one-third as much glycine as methionine from serine.

Using $\left.{ }^{[14} \mathrm{C}-2\right]$ serine it has now been shown that $\mathrm{C}-2$ of serine is incorporated into the methyl group of methionine by organisms grown with glycine, though not with serine. This result shows that C-2 of glycine (formed from serine by serine hydroxymethylase) can also act as source of the $C_{1}$ unit for methionine synthesis. Dialysed ultrasonic extracts of glycine-grown organisms in the presence of tetrahydrofolate formed $\mathrm{C}_{1}$ units (isolated as $\left[{ }^{14} \mathrm{C}\right]$ formaldmethone) from $\left[{ }^{14} \mathrm{C}-2\right]$ glycine ; only ${ }^{14} \mathrm{CO}_{2}$ was formed from $\left[{ }^{14} \mathrm{C}-1\right]$ glycine. Chromatography on TEAE-cellulose of products with $\left[{ }^{14} \mathrm{C}-1\right]$ or $\left[{ }^{14} \mathrm{C}-2\right]$ glycine as substrate showed that radioactive formaldehyde and tetrahydrofolate derivatives were formed only from $\left[{ }^{14} \mathrm{C}-2\right]$ glycine. These results are consistent with those of Pitts, J. D. \& Crosbie, G. W. ((1962), Biochem. J. 83, 35 P).

Growth in the presence of serine (even if glycine is also present) represses the formation of the enzyme system for the production of $\mathrm{C}_{1}$ units (at the formaldehyde level of oxidation) from glycine. Relief from repression occurs on transfer of serine-grown organisms to media containing glycine only and is inhibited by chloramphenicol. When glycine-grown organisms are transferred to a medium containing serine, glycine metabolism is repressed and ability to synthesize methionine (serine as $\mathrm{C}_{1}$ donor) also decreases at a rate consistent with the dilution out of a mechanism for the utilization of $\mathrm{C}-2$ (though not of $\mathrm{C}-3$ ) of serine.

\section{Amino Acid Accumulation as a Consequence of Respiration in Bacillus megaterium. By R. E. MARqUIS(Chemical Biology Unit, Zoology Department, Edinburgh University)}

There is a great deal of evidence suggesting that the transport of certain molecules into cells can be an energy-requiring process and so must be coupled to some exergonic reaction. Such a couple can be demonstrated in Bacillus megaterium between respiration and the uptake of alpha-aminoisobutyrate, a metabolically inert amino acid that enters these cells by the normal pathways for glycine and alanine. In the absence of respiration, at $4^{\circ}$ or under a nitrogen atmosphere, this amino acid is taken up passively only, the uptake being essentially the same at $4^{\circ}$ as at $30^{\circ}$. During respiration, uptake occurs also by mechanisms linked to oxygen utilization and, therefore, metabolic degradation of compounds such as glucose, succinate or lactate leads to increases in amino acid uptake in proportion to the extent that oxygen uptake is accelerated. This respiration-dependent uptake can be completely reversed by placing the cells in a nitrogen atmosphere or by allowing them to deplete their oxidizable substrates.

Since amino acid uptake by this organism is directly related to oxygen uptake, it can be stimulated by agents such as arsenate or dinitrophenol, when these speed up respiration, and inhibited by agents such as cyanide that block oxidation. The coupling between amino acid uptake and respiration is of a nature that changes in the rate of respiration are reflected by amino acid movement only after a brief time lag. That is to say, the primary asymmetry between the cell and its environment is caused by respiration, amino acid accumulation representing only a response to this unstable condition. The rate of oxygen utilization required to maintain a particular concentration differential between interior and exterior of the cell is a function of the work involved in the concentration process. Some details of this function will be presented.

The Effect of Antibiotics on Fixation of Penicillin by Sensitive Bacteria. By P. E. Reynolds (Sub-Department of Chemical Microbiology, Department of Biochemistry, University of Cambridge) 